\title{
Korelasi Antar Sub Pokok Bahasan Termokimia Pada Siswa Kelas XI MIPA SMA Negeri Palangka Raya Tahun Ajaran 2018/2019
}

\author{
Novitasari \\ Program Studi Pendidikan Kimia, Universitas Palangka Raya, Indonesia \\ E-mail: novitachemeduupr@gmail.com
}

Diterima: 01-10-2021; Diperbaiki:06-10-2021; Disetujui:07-10-2021

\begin{abstract}
ABSTRAK
Penelitian ini bertujuan untuk mendeskripsikan korelasi antar sub pokok bahasan termokimia berdasarkan nilai koefisien korelasi dan korelasi antar sub pokok bahasan termokimia berdasarkan nilai rata-rata (mean) hasil tes. Penelitian ini merupakan penelitian deskripstif yang menggunakan pendekatan kuantitatif dan termasuk dalam jenis penelitian korelasional. Subjek dalam penelitian ini adalah siswa kelas XI MIPA SMA Negeri 1 Palangka Raya, SMA Negeri 2 Palangka Raya, dan SMA Negeri 4 Palangka Raya tahun ajaran 2018/2019 dengan total 514 siswa. Data yang digunakan berupa data kemampuan siswa terhadap konsep termokimia yang ditunjukkan dengan ketercapaian indikator. Data dijaring melalui tes menggunakan soal pilihan ganda (TKT) sebanyak 32 soal. Data tes kemampuan siswa berupa jawaban dianalisis menggunakan metode korelasi dan deskriptif. Hasil penelitian menunjukkan bahwa urutan penyajian sub pokok bahasan termokimia berdasarkan nilai koefisien korelasi, yaitu: (1) energi ikatan (ENIKA), (2) kalor dan perubahan entalpi reaksi (KPER), (3) persamaan temokimia (PETER), (4) perubahan entalpi standar untuk berbagai reaksi (PESBR), dan (5) penentuan perubahan entalpi reaksi (PENER).Urutan penyajian sub pokok bahasan berdasarkan nilai rata-rata (mean) hasi tes siswa, yaitu: (1) kalor dan perubahan entalpi reaksi (KPER), (2) persamaan termokimia (PETER), (3) penentuan perubahan entalpi reaksi (PENER), (4) perubahan entalpi standar untuk berbagai reaksi (PESBR), dan (5) energi ikatan (ENIKA). Urutan penyajian di atas berbeda dengan urutan berdasarkan silabus.
\end{abstract}

Kata Kunci : Korelasi, termokimia, urutan penyajian materi, koefisien korelasi, mean.

\section{PENDAHULUAN}

Amri (2013) mengemukakan urutan penyajian (sequencing) berguna untuk menentukan urutan proses pembelajaran. Tanpa urutan yang tepat, jika di antara beberapa materi pembelajaran mempunyai hubungan yang bersifat prasyarat (prerequisite) akan menyulitkan siswa dalam mempelajarinya. Umumnya urutan materi kimia disusun berdasarkan hasil pemikiran para ahli. Urutan yang disusun para ahli pada silabus pokok bahasan termokimia adalah yang pertama kalor dan perubahan entalpi reaksi, kedua persamaan termokimia, ketiga perubahan entalpi standar $\left(\Delta H^{0}\right)$ untuk berbagai reaksi, keempat energi ikatan rata-rata, dan kelima penentuan perubahan entalpi reaksi.

Observasi pada buku kimia SMA kelas XI menyatakan bahwa urutan pada pokok bahasan termokimia adalah pertama kalor dan perubahan entalpi reaksi, kedua persamaan termokimia, ketiga perubahan entalpi standar $\left(\Delta H^{0}\right)$ untuk berbagai reaksi, keempat energi ikatan rata-rata, dan kelima penentuan 
perubahan entalpi reaksi. Hasil observasi menunjukkan bahwa terjadi perubahan urutan pada sub pokok bahasan termokimia yaitu terletak pada urutan keempat dan kelima. Silabus menerangkan bahwa urutan keempat adalah energi ikatan rata-rata dan kelima penentuan perubahan entalpi reaksi, sedangkan pada buku kimia menerangkan bahwa urutan keempat adalah penentuan perubahan entalpi reaksi dan kelima adalah energi ikatan rata-rata.

Jonedi (2016) mengemukakan berdasarkan hasil penelitiannya bahwa susunan materi pokok pelajaran kimia kurikulum 2013 semester ganjil berdasarkan koefisien korelasi adalah Termokimia (bab 2) - Kesetimbangan (bab 4) - Laju Reaksi (bab 3) - Hidrokarbon (bab 1). Sedangkan berdasarkan skor ratarata (mean) hasil tes atau tingkat kesukaran adalah Hidrokarbon (bab 1) - Laju Reaksi (bab 3) - Kesetimbangan (bab 4) - Termokimia (bab 2). Hal tersebut menunjukkan bahwa terjadi perubahan urutan materi yang artinya guru tidak harus mengajarkan materi sesuai urutan yang ditetapkan pada silabus dan buku pelajaran kimia di SMA melainkan disarankan berdasarkan urutan materi yang sesuai dengan kebutuhan siswa.

Selain itu, Alina (2018) juga melakukan penelitian tentang korelasi. Hasil penelitiannya menyatakan bahwa urutan materi berdasarkan nilai koefisien korelasi yakni dimulai dari sub 1 Hukum Kekekalan Massa (Hukkesa), sub 4 Hukum perbandingan Berganda (Hukdingda), sub 3 Hukum Perbandingan Volume (Hukdinglume) dan diakhiri dengan sub 2 Hukum Perbandingan Tetap (Hukdingtap). Namun jika dilihat dari skor rata-rata (mean) hasil tes atau tingkat kesukaran, urutan materi dimulai dari sub 2 Hukum Perbandingan Tetap (Hukdingtap), sub 1 Hukum Kekekalan Massa (Hukkesa), sub 4 Hukum Perbandingan Berganda (Hukdingda), dan diakhiri dengan sub 3 Hukum Perbandingan Volume (Hukdinglume). Hasil penelitian di atas menunjukkan bahwa terjadi perbedaan urutan penyajian materi terhadap silabus baik berdasarkan nilai koefisien korelasi maupun berdasarkan tingkat kesukaran (mean). Meskipun begitu jika diAMATI, urutan penyajian materi baik berdasarkan nilai koefisien korelasi maupun tingkat kesukaran (mean) sub 1 (Hukkesa) memiliki hubungan yang erat dengan sub 4 (Hukdingda). Hubungan tersebut menunjukkan bahwa untuk dapat menguasai konsep Hukdingda terlebih dahulu kuasai konsep Hukkesa dalam artian lain Hukkesa merupakan prasyarat untuk Hukdingda. Begitu pula dengan konsep Hukdinglume di mana Hukdingda merupakan prasyarat untuk konsep ini.

Terkait hal inilah pentingnya korelasi, di mana dengan korelasi dapat diamati hubungan antar sub pokok bahasan sehingga dapat ditentukan urutan penyajiannya yang mana harus diajarkan terlebih dahulu karena merupakan prasyarat dan mana yag diajarkan diakhir. Maka dari itu dilakukanlah penelitian tentang korelasi pada sub pokok bahasan termokimia berdasarkan dari hubungan atau nilai koefisien korelasi dan skor rata-rata (mean) hasil tes kemampuan siswa pada tiap sub pokok bahasan terutama di kelas XI MIPA. Dengan menghitung 
korelasi antar sub pokok bahasan termokimia menggunakan tes tertulis peneliti dapat menentukan urutan materi pokok bahasan termokimia dengan mengkorelasikan hasil tes kemampuan siswa dan membandingkan hasilnya dengan urutan penyajian materi pokok bahasan termokimia yang telah ditentukan oleh para ahli. Penelitian ini dibatasi oleh 3 hal, yaitu: (1) urutan sub pokok bahasan yang dianalisis adalah urutan sub pokok bahasan termokimia pada kelas XI MIPA yang terdiri dari 5 sub pokok bahasan yaitu kalor dan perubahan entalpi reaksi, persamaan termokimia, perubahan entalpi standar $\left(\Delta H^{0}\right)$ untuk berbagai reaksi, energi ikatan rata-rata, dan penentuan perubahan entalpi reaksi yang diterpkan kurikulum 2013. (2) Khusus sub pokok bahasan perubahan entalpi standar $\left(\Delta H^{0}\right)$ untuk berbagai reaksi dalam penelitian ini dibatasi hanya reaksi pembentukkan standar $\left(\Delta H_{f}^{0}\right)$, reaksi penguraian standar $\left(\Delta H_{d}^{0}\right)$, dan reaksi pembakaran standar $\left(\Delta H_{c}^{0}\right)$. (3) Parameter yang diteliti ada dua yaitu berdasarkan nilai koefisien korelasi dan nilai rata-rata (mean) hasil tes.

\section{METODOLOGI PENELITIAN}

Penelitian ini merupakan penelitian korelasional. Waktu Tempat, dan subjek penelitian ditampilkan pada Tabel 1 .

Tabel 1. Waktu, Tempat dan Subjek Penelitian

\begin{tabular}{|c|c|c|c|c|c|}
\hline Nama Sekolah & $\begin{array}{l}\text { Kode } \\
\text { Sekolah }\end{array}$ & $\begin{array}{l}\text { Kelas } \\
\text { XI } \\
\text { MIPA }\end{array}$ & $\begin{array}{l}\text { Jumlah } \\
\text { Penelitian }\end{array}$ & Subjek & Tanggal Pengambilan Data \\
\hline \multirow{6}{*}{$\begin{array}{c}\text { SMAN 1 } \\
\text { Palangka Raya }\end{array}$} & \multirow{6}{*}{ A } & 2 & 35 & \multirow{6}{*}{$\begin{array}{c}\text { Sub } \\
\text { total } \\
209\end{array}$} & 1 November 2018 \\
\hline & & 3 & 36 & & 1 November 2018 \\
\hline & & 4 & 35 & & 22 November 2018 \\
\hline & & 5 & 34 & & 22 November 2018 \\
\hline & & 6 & 34 & & 29 November 2018 \\
\hline & & 7 & 35 & & 28 November 20118 \\
\hline \multirow{5}{*}{$\begin{array}{c}\text { SMAN } 2 \\
\text { Palangka Raya }\end{array}$} & \multirow{5}{*}{ B } & 3 & 38 & \multirow{5}{*}{$\begin{array}{c}\text { Sub } \\
\text { total } \\
189\end{array}$} & 16 November 2018 \\
\hline & & 4 & 38 & & 21 November 2018 \\
\hline & & 5 & 37 & & 22 November 2018 \\
\hline & & 6 & 41 & & 21 November 2018 \\
\hline & & 7 & 35 & & 27 November 2018 \\
\hline \multirow{5}{*}{$\begin{array}{c}\text { SMAN } 4 \\
\text { Palangka Raya }\end{array}$} & \multirow{5}{*}{$\mathrm{C}$} & 1 & 17 & \multirow{5}{*}{$\begin{array}{c}\text { Sub } \\
\text { total } \\
116\end{array}$} & 11 Desember 2018 \\
\hline & & 2 & 33 & & 11 Desember 2018 \\
\hline & & 3 & 21 & & 11 Desember 2018 \\
\hline & & 5 & 31 & & 29 November 2018 \\
\hline & & 6 & 14 & & 11 Desember 2018 \\
\hline Total Subjek & & & 514 & & \\
\hline
\end{tabular}

Asumsi penelitian ini adalah bahwa materi termokimia telah dipelajari oleh siswa khususnya kelas XI MIPA . Instrumen yang digunakan dalam penelitian ini adalah tes kemampuan termokimia (TKT) berupa soal pilihan 
ganda. Soal pada TKT dipilih dari buku-buku SMA kelas XI MIPA kemudian dimodifikasi sebagian. Bagian yang dimodifikasi berupa angka, kata, persamaan reaksi maupun hal yang ditanyakan pada soal. Instrumen penelitian ini dikembangkan sesuai indikator dan mengacu pada kurikulum 2013 edisi revisi 2016.

Rancangan TKT sebelum digunakan terlebih dahulu diuji validitasnya. Rancangan TKT divalidasi oleh 3 orang rater, dua orang dari dosen pendidikan kimia UPR dan satu orang dari guru SMA Negeri Palangka Raya. Validasi yang dilakukan meliputi validasi isi rancangan TKT dan materi termokimia. Tingkat kesesuaian antara indikator terhadap soal yang dinilai oleh rater dengan memberikan skor "2" jika soal dianggap sangat sesuai dengan indikator, skor " 1 " jika soal dianggap sesuai dengan indikator, dan skor "0" jika soal dianggap tidak sesuai. Tahap selanjutnya rerata skor dihitung untuk tiap soal. Jika rerata skor kurang dari atau sama dengan "0,50" soal dibuang, "0,50-1,0" soal direvisi, dan lebih dari "1,1" maka soal diterima. Tingkat kesesuaian ini merupakan bukti kesahihan isi pernyataan dalam Tes Kemampuan Termokimia (TKT). Uji coba rancangan TKT dilaksanakan sebelum pengambilan data penelitian. Pelaksanaan uji coba rancangan TKT dilakukan pada tanggal 25 Oktober 2018. Tujuan dilakukannya uji coba adalah untuk mengetahui reliabilitas, daya beda, tingkat kesukaran dan keterbacaan butir soal. Teknik mengumpulkan dan analisis data disajikan pada Tabel 2 .

\section{Tabel 2. Data, Cara Pengumpulan dan cara Analsis Data}

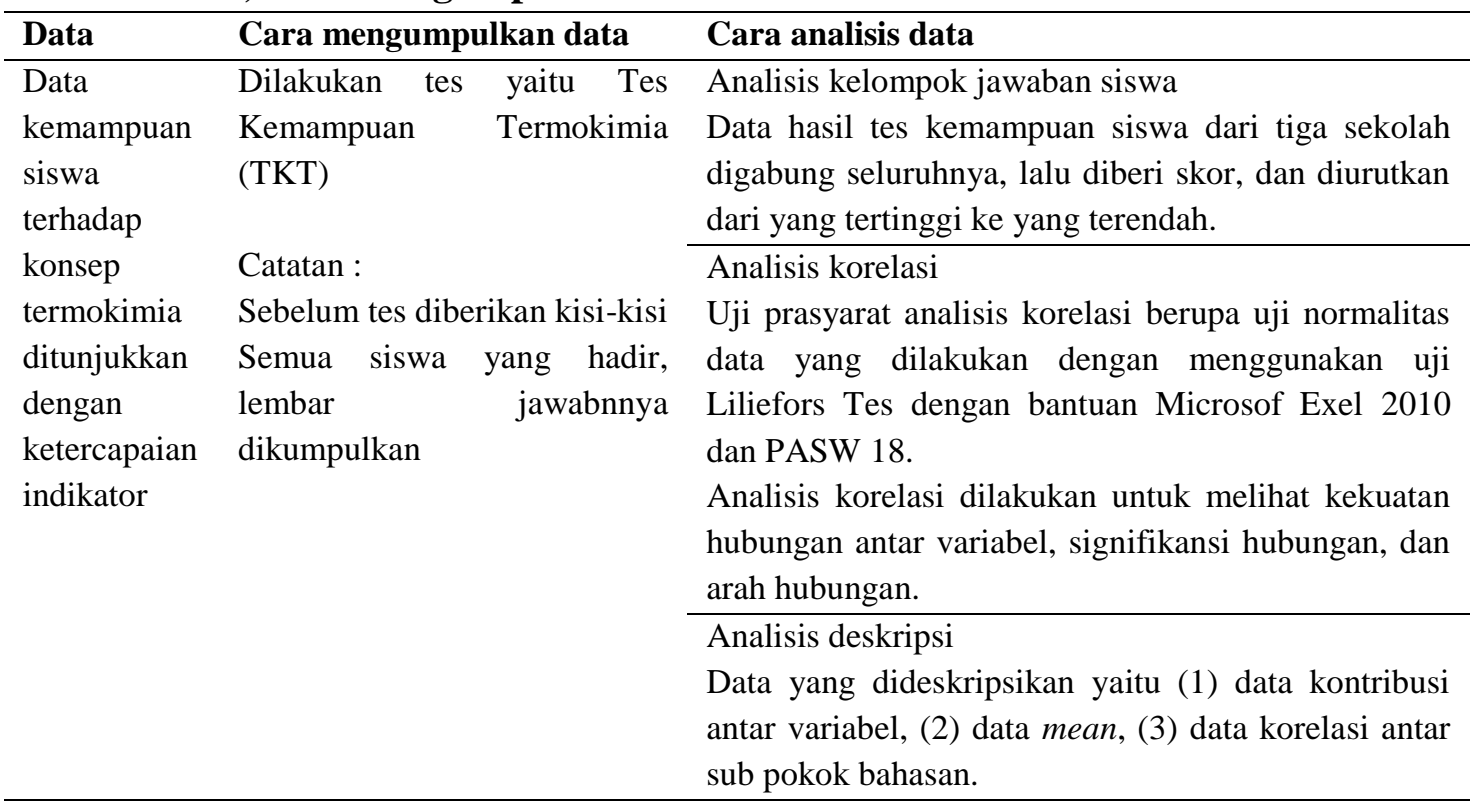

\section{HASIL DAN PEMBAHASAN}

\section{Hasil Penelitian}

Sebelum analisis korelasi dilakukan, data diuji normalitasnya terlebih dahulu. Hal ini karena uji parametrik (Pearson) mensyaratkan bahwa data harus 
berdistribusi normal. Uji normalitas data dilakukan menggunakan uji Liliefors Test. Hasil uji menunjukkan bahwa data tidak berdistribusi normal sehingga alternatif lain yaitu mengganti uji dari yang parametrik menjadi nonparametrik. Analisis korelasi dengan uji nonparametrik digunakan analisis Kendall's tau-b Coefficient of Correlation (koefisien korelasi Kendall tau-b). Analisis ini tidak mensyaratkan bahwa data harus berdistribusi normal. Analisis ini juga digunakan sebagai alternatif dalam analisis korelasi jika syarat analisis pearson tidak terpenuhi. Hasil Analisis korelasi disajikan pada Tabel 3.

Tabel 3. Nilai Koefisien Korelasi Sampel Seluruh Sekolah

\begin{tabular}{|c|c|c|c|c|c|c|}
\hline & & KPER & PETER & PESBR & ENIKA & PENER \\
\hline \multirow[t]{3}{*}{ KPER } & Kendall's tau-b & 1 & 0,947 & $\mathbf{0 , 8 9 2}$ & 0,925 & 0,913 \\
\hline & Asymp.std.error ${ }^{\mathrm{a}}$ & & 0,005 & 0,005 & 0,006 & 0,006 \\
\hline & $\mathrm{N}$ & 514 & 514 & 514 & 514 & 514 \\
\hline \multirow[t]{3}{*}{ PETER } & Kendall's tau-b & 0,947 & 1 & 0,896 & $\mathbf{0 , 8 9 9}$ & 0,941 \\
\hline & Asymp.std.error ${ }^{\mathrm{a}}$ & 0,005 & & 0,005 & 0,006 & 0,006 \\
\hline & $\mathrm{N}$ & 514 & 514 & 514 & 514 & 514 \\
\hline \multirow[t]{3}{*}{ PESBR } & Kendall's tau-b & 0,892 & 0,896 & 1 & $\mathbf{0 , 8 8 7}$ & 0,894 \\
\hline & Asymp.std.error ${ }^{a}$ & 0,005 & 0,005 & & 0,007 & 0,006 \\
\hline & $\mathrm{N}$ & 514 & 514 & 514 & 514 & 514 \\
\hline \multirow[t]{3}{*}{ ENIKA } & Kendall's tau-b & 0,925 & $\mathbf{0 , 8 9 9}$ & $\mathbf{0 , 8 8 7}$ & 1 & $\mathbf{0 , 8 7 7}$ \\
\hline & Asymp.std.error ${ }^{\mathrm{a}}$ & 0,006 & 0,006 & 0,007 & & 0,006 \\
\hline & $\mathrm{N}$ & 514 & 514 & 514 & 514 & 514 \\
\hline \multirow[t]{3}{*}{ PENER } & Kendall's tau-b & 0,913 & 0,941 & 0,894 & $\mathbf{0 , 8 7 7}$ & 1 \\
\hline & Asymp.std.error ${ }^{\mathrm{a}}$ & 0,006 & 0,006 & 0,006 & 0,006 & \\
\hline & $\mathrm{N}$ & 514 & 514 & 514 & 514 & 514 \\
\hline
\end{tabular}

Ada tiga penafsiran hasil analisis korelasi, yaitu kekuatan hubungan antar variabel, signifikansi hubungan dan arah hubungan. Analisis korelasi untuk seluruh sekolah dengan taraf probabilitas (signifikan) 5\% pada masing-masing sub pokok bahasan diperoleh nilai koefisien korelasi lebih dari 0,8. Sesuai kriteria, korelasi antar sub pokok bahasan termokimia termasuk dalam tingkat korelasi yang sangat kuat. Ini berarti bahwa semakin mudah memahami konsep awal (KPER), membantu siswa untuk memahami konsep selanjutnya. Korelasi dapat bernilai positif (searah) atau negatif (berlawanan arah). Hasil analisis menunjukkan koefisien korelasi bernilai positif yang artinya hubungan antar variabel searah. Signifikansi hubungan ditentukan menggunakan pengujian hipotesis yang dilakukan dengan cara membandingkan angka signifikan terhadap taraf sig. 5\% (0,05). Keputusan yang diperoleh dari hasil analisis yakni angka signifikansi $0,005-0,007<0,05$, artinya $\mathrm{H}_{0}$ ditolak, hubungan antar sub pokok bahasan termokimia signifikan. 


\section{Pembahasan}

Suatu materi pelajaran disusun dalam rangka untuk mencapai tujuan pembelajaran. Setiap rangkaiannya dimuat ide-ide pokok yang mencakup kompetensi dan indikator pelajaran. Urutan materi pelajaran secara hierarkis menggambarkan urutan yang bersifat berjenjang dari atas ke bawah atau sebaliknya. Materi sebelumnya harus dipelajari terlebih dahulu sebagai prasyarat materi berikutnya. Materi pelajaran dapat diurutkan dengan mengetengahkan tentang sekuen. Urutan materi didasarkan pada sekuens kronologis, kausual, struktural, logis dan psikologis, spiral, rangkaian kebelakang dan hierarki belajar. Sekuens yang dibahas dalam skripsi ini adalah sekuens logis dan psikologis. Menurut sekuens logis susunan materi pelajaran dimulai dari yang sederhana menuju kepada yang kompleks sedangkan sekuens psikologis sebaliknya, yakni dari yang kompleks menuju yang sederhana.

Urutan penyajian materi termokimia dimulai dengan KPER. Konsep ini dianggap merupakan prasyarat karena memuat konsep dasar untuk konsep selanjutnya. Konsep ini dibahas tentang pengertian kalor dan perubahan entalpi reaksi, sistem dan lingkungan, serta reaksi eksoterm dan endoterm. Urutan kedua yaitu PETER. Konsep PETER berisi tentang persamaan termokimia sehingga dapat dikatakan konsep ini merupakan prasyarat untuk konsep selanjutnya. Banyak hal penting yang harus dikuasai oleh siswa dalam konsep ini diantaranya yaitu fase atau wujud zat, koefisien yang menyatakan jumlah mol zat, kaitan antara perubahan entalpi dengan jumlah zat di mana jika reaksi dibalik, dikali, dibagi, dan dijumlahkan maka akan mempengaruhi nilai perubahan entalpinya.

\begin{tabular}{|c|c|c|c|c|}
\hline KPER & PETER & PESBR & ENIKA & PENER \\
\hline 1 & 2 & 3 & 4 & 5 \\
\hline
\end{tabular}

\section{Gambar 1. Urutan penyajian berdasakan silabus}

Urutan penyajian sub pokok bahasan selanjutnya yaitu PESBR. Konsep ini memuat tentang berbagai reaksi kimia standar seperti reaksi pembentukkan, penguraian, pembakaran, penetralan, penguapan, dan lain-lain. Reaksi yang dibahas dalam skripsi ini hanya tiga yaitu reaksi pembentukkan, penguraian dan pembakaran. Konsep ini dapat dikuasai apabila siswa telah memahami dengan baik mengenai konsep PETER. Urutan penyajian sub pokok bahasan selanjutnya yakni ENIKA. Hal yang dibahas dalam konsep ini adalah tentang cara menentukan entalpi reaksi berdasarkan data energi ikatan. Konsep ini akan mudah dikuasai jika siswa telah mampu membuat rumus struktur suatu senyawa. Selain itu, siswa juga harus menguasai keterkaitan antara koefisien reaksi dengan jumlah mol zat.

Urutan penyajian sub pokok bahasan yang terakhir yaitu PENER. Konsep ini berisi tentang penentuan entalpi berdasarkan tiga cara yakni kalorimeter, 
hukum Hess, dan data entalpi pembentukkan standar. Konsep ini dapat dikuasai dengan mudah apabila siswa telah memahami konsep sebelumnya khususnya PETER dan PESBR.

\section{Deskripsi korelasi antar sub pokok bahasan termokimia berdasarkan nilai koefisien korelasi pada seluruh sekolah}

Korelasi antar sub pokok bahasan termokimia terbagi menjadi 5 hubungan, yaitu hubungan antar sub pokok bahasan: 1) Kalor dan perubahan entalpi reaksi (KPER); 2) Persamaan termokimia (PETER); 3) Perubahan entalpi untuk berbagai reaksi (PESBR); 4) Energi ikatan (ENIKA); dan 5) Penentuan entalpi reaksi (PENER). Simbol yang digunakan sebagai batas korelasi suatu sub pokok bahasan dengan sub pokok bahasan lainnya adalah simbol dengan nilai koefisien korelasi "1" pada masing-masing sub pokok bahasan. Data pada Grafik 1 menunjukkan kedekatan antar sub pokok bahasan. Nilai koefisien korelasi terbesar yaitu PETER, KPER, PENER, ENIKA, dan yang terakhir PESBR. Kekuatan korelasi dan kedekatan hubungan antar sub pokok bahasan bisa diamati dari besarnya nilai koefisien korelasi suatu sub pokok bahasan dengan sub pokok bahasan lainnya. Nilai koefisien korelasi yang semakin mendekati "1", berarti bahwa hubungannya semakin kuat. Nilai koefisien korelasi yang semakin menjauhi "1", berarti bahwa hubungannya akan semakin lemah. Arah hubungan dari korelsi antar sub pokok bahasan termokimia dapat diinterpretasikan pada Grafik 2 .

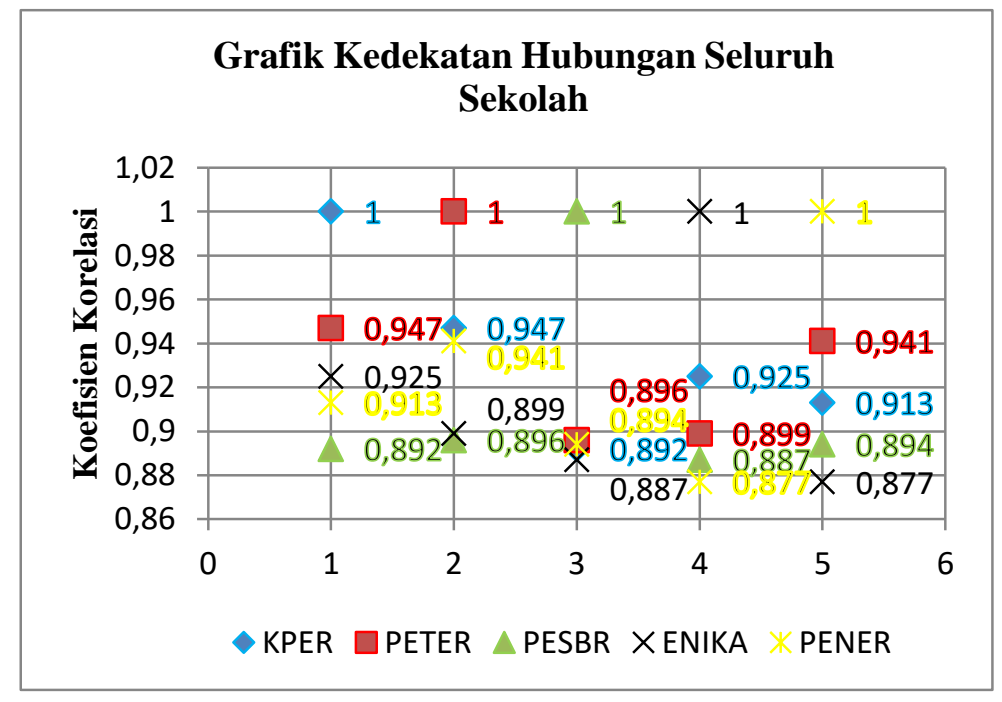

Grafik 1. Kedekatan Hubungan 


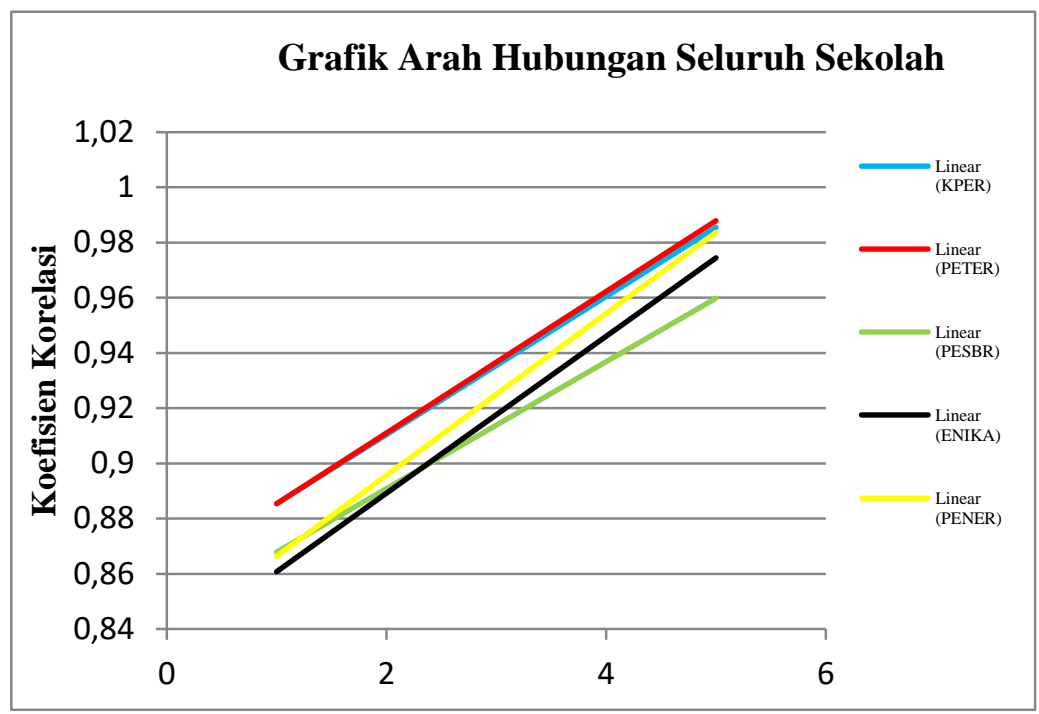

Grafik 2. Arah Hubungan

Data pada Grafik 2 menunjukkan bahwa korelasi pada seluruh sub pokok bahasan memiliki arah yang sama dan bernilai positif. Artinya, pemahaman konsep pada sub pokok bahasan yang satu akan berpengaruh terhadap pemahaman konsep sub pokok bahasan yang lain. Sub pokok bahasan KPER dan PETER memiliki kedekatan yang kuat, terlihat dari garis kedua sub pokok bahasan ini yang semakin berimpit. Sub pokok bahasan PENER searah namun memiliki kedekatatan yang lemah dari kedua sub pokok bahasan di atas. sama halnya dengan sub pokok bahasan ENIKA dan PESBR yang memiliki kedekatan lemah dengan ketiga sub pokok bahasan lainnya, namun kedua sub pokok bahasan ini memiliki kedekatan hubungan, terlihat dari garis kedua sub pokok bahasan ini sedikit bersinggungan dan searah.

Deskripsi urutan penyajian materi berdasarkan kekuatan dan kedekatan dari nilai koefisien korelasi antar sub pokok bahasan termokimia, dapat dilihat pada Gambar 2.

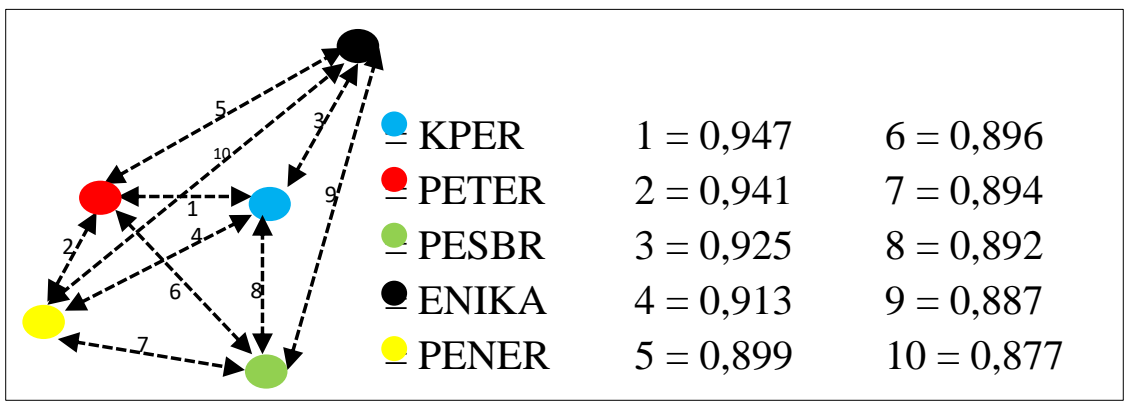

Gambar 2. Korelasi Antar Sub Pokok Bahasan Termokimia Seluruh Sekolah 
Jarak antara garis putus-putus (garis hubungan) yang satu dengan yang lain digambarkan berdasarkan nilai koefisien korelasi pada Tabel 3. Garis hubung yang semakin pendek menunjukkan semakin besar nilai koefisien korelasinya. Begitu pula sebaliknya, garis hubung yang semakin panjang menunjukkan semakin kecil nilai koefisien korelasinya. Gambar 2 menunjukkan bahwa sub pokok bahasan PETER merupakan sub pokok bahasan yang paling dekat dengan keempat sub pokok bahasan lainnya. Sub pokok bahasan ini merupakan puncak karena memiliki nilai koefisien korelasi tertinggi. Sub pokok bahasn PETER paling dekat dengan sub pokok bahasan KPER (korelasi = 0,947), lalu dengan sub pokok bahasan PENER (korelasi $=0,941$ ), kemudian sub pokok bahasan ENIKA (korelasi $=0,899$ ), dan yang telakhir pokok bahasan PESBR (korelasi $=0,896$ ).

Nilai koefisien korelasi antar sub pokok bahasan termokimia disusun dari sub pokok bahasan dengan korelasi yang paling signifikan. Urutan sub pokok bahasan termokimia berdasarkan nilai koefisien dimulai dari korelasi pada sub pokok bahasan KPER terhadap sub pokok bahasan PETER, PESBR, ENIKA, dan PENER ditampilkan pada Gambar 3.

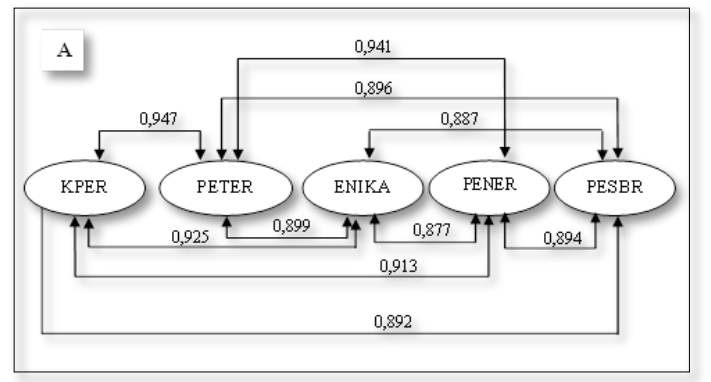

\section{Gambar 3a. Korelasi Antara KPER Terhadap PETER, ENIKA, PENER dan PESBR}

Gambar 3a menginformasikan bahwa urutan penyajian sub pokok bahasan termokimia dimulai dari KPER, dilanjutkan dengan PETER, ENIKA, PENER, dan terakhir PESBR. Sub pokok bahasan KPER memiliki korelasi yang paling tinggi terhadap PETER. Hal ini disebabkan karena pada kedua sub pokok bahasan ini sama-sama membahas tentang reaksi eksoterm dan endoterm sehingga saling berpautan. Sub pokok bahasan KPER memuat konsep tentang perpindahan kalor dari sistem ke lingkungan atau sebaliknya sehingga menyebabkan dikenal dua reaksi yakni reaksi eksoterm dan endoterm. Sub pokok bahasan PETER memuat konsep tata cara penulisan reaksi eksoterm dan endoterm yang disertai dengan energinya. Reaksi eksoterm memiliki entalpi bertanda negatif karena sistem melepaskan kalor sedangkan untuk reaksi endoterm sebaliknya. 


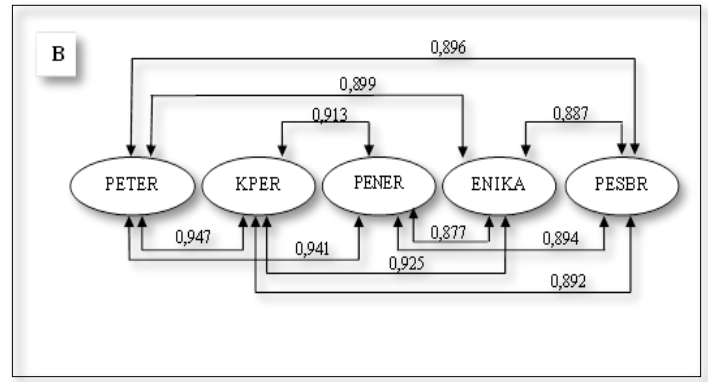

\section{Gambar 3b. Korelasi Antara PETER Terhadap KPER, PENER, ENIKA dan PESBR}

Gambar 3b menginformasikan bahwa urutan penyajian pokok bahasan termokimia dimulai dari PETER, dilanjutkan dengan KPER, PENER, ENIKA dan PESBR. Hasil penelitian menunjukkan korelasi antara PETER dengan KPER paling tinggi karena ditinjau dari segi konsep kedua sub pokok bahasan ini membahas konsep yang sama yakni reaksi eksoterm dan endoterm. Konsep yang dibahas pada PETER adalah tata cara penulisan kedua reaksi tersebut yang disertai dengan energinya. Reaksi endoterm memiliki entalpi bertanda positif karena sistem menerima kalor sedangkan untuk reaksi eksoterm sebaliknya. Konsep yang dibahas pada KPER adalah perpindahan kalor dari sistem ke lingkungan atau sebaliknya yang menyebabkan dikenal dua reaksi kimia yakni eksoterm dan endoterm.

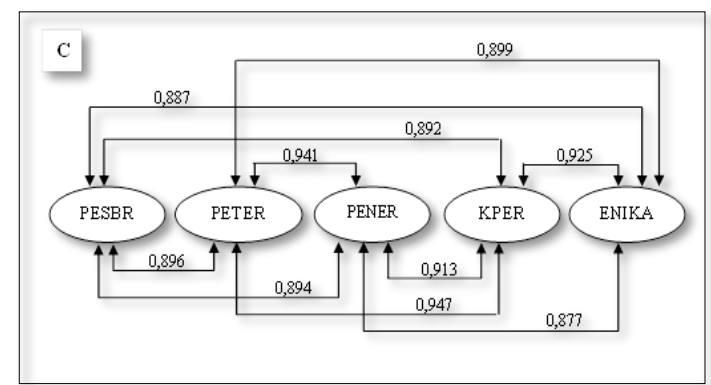

\section{Gambar 3c. Korelasi Antara PESBR Terhadap PETER, PENER, KPER, dan ENIKA.}

Urutan penyajian pada pokok bahasan termokimia sebagaimana diinformasikan pada Gambar 3c dimulai dari PESBR, kemudian PETER, PENER, KPER dan terakhir ENIKA. Sub pokok bahasan PESBR berada pada urutan pertama karena pada sub pokok bahasan ini memuat konsep berupa fakta yakni data entalpi untuk berbagai reaksi-reaksi standar. Contohnya reaksi pembentukkan amonia berikut.

$$
\frac{1}{2} N_{2}(g)+\frac{3}{2} H_{2}(g) \rightarrow N_{3}(g) \Delta H=-46,1 k J
$$

Reaksi tersebut merupakan konsep fakta. Hal ini disebabkan karena pada kenyataannya untuk membentuk 1 mol gas amonia dari unsur-unsurnya dihasilkan energi sebesar 46,1 kJ. Konsep fakta mudah dimengerti oleh siswa karena dalam 
memahaminya cukup melibatkan indera penglihatan atau pendengaran saja. Sub pokok bahasan kedua setelah PESBR adalah PETER. PETER merupakan persamaan termokimia yang memuat konsep tentang tata cara penulisan reaksireaksi kimia beserta energinya. Reaksi-reaksi yang dimaksud dapat berupa reaksi standar dan tidak standar. Reaksi standar yang dibahas pada PETER inilah yang berkaitan dengan PESBR sehingga PETER berada pada urutan kedua setelah PESBR. Contohnya penulisan reaksi pembentukkan amonia di atas. reaksi tersebut dituliskan dengan menyertakan wujud unsur atau senyawa, jumlah masing-masing unsur atau senyawa, dan energi yang menyertai pembentukkan 1 mol amonia tersebut.

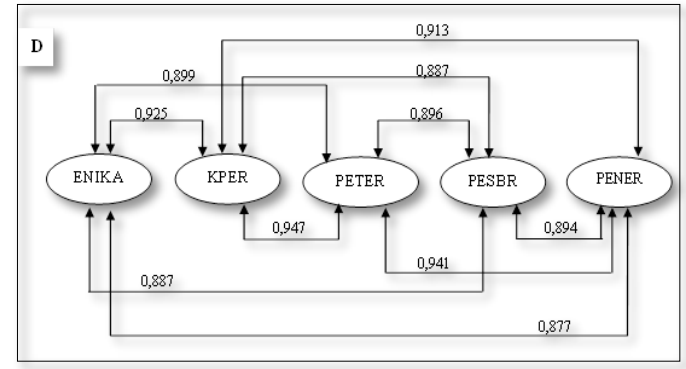

\section{Gambar 3d. Korelasi Antara ENIKA Terhadap KPER, PETER, PESBR, dan PENER}

Urutan penyajian pokok bahasan termokimia sebagaimana ditampilkan pada Gambar 3d, berawal dari ENIKA kemudian dilanjutkan dengan KPER. Korelasi antara kedua sub pokok bahasan ini cukup besar. Sub pokok bahasan ENIKA memuat konsep fakta berupa data-data energi ikatan suatu unsur. Contohnya energi ikatan antara unsur hidrogen dengan hidrogen sebagai berikut.

$$
\mathrm{H}_{2}(g) \rightarrow 2 \mathrm{H} \quad D_{H-H}=436,0 \mathrm{~kJ}
$$

Energi yang dimaksud adalah energi yang diperlukan sistem baik untuk membentuk ikatan maupun untuk memutuskan ikatan. Konsep energi yang dibahas pada ENIKA juga dibahas pada KPER. Energi pada kedua sub pokok bahasan ini kemudian dikenal dengan entalpi karena diukur pada tekanan tetap. Alasan inilah yang menyebabkan kedua sub pokok bahasan ini saling bersangkutan.

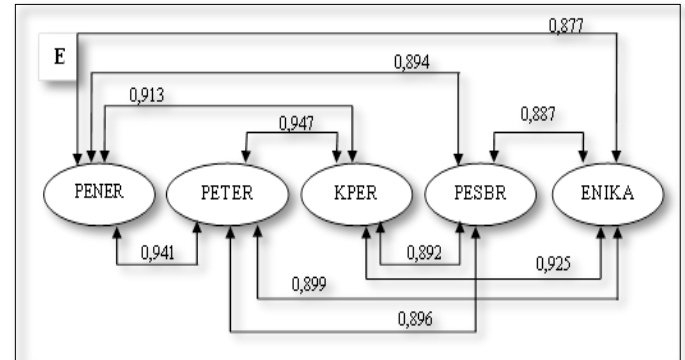

Gambar 3e. Korelasi Antara PENER Terhadap PETER, KPER, PESBR, dan ENIKA 
Hasil penelitian menunjukkan bahwa Sub pokok bahasan PENER memiliki korelasi yang paling tinggi terhadap PETER. Kedua sub pokok bahasan ini memiliki konsep yang sama yakni memuat konsep reaksi kimia. Ditinjau dari segi konsep sub pokok bahasan PETER merupakan prasyarat untuk PENER. Hal ini karena reaksi eksoterm dan endoterm yang dibahas pada PETER digunakan untuk menentukan perubahan entalpi pada PENER khususnya penentuan entalpi berdasarkan hukum Hess. Reaksi tersebut disajikan dalam bentuk diagram tingkat energi, diagram siklus, dan reaksi-reaksi berhubungan.

Korelasi antar sub pokok bahasan termokimia dapat diurutkan sebagai urutan penyajian materi.urutan penyajian sub pokok bahasan termokimia berdasarkan nilai koefisien korelasi seluruh sekolah yang dapat dicoba untuk diterapkan dalam kegiatan pembelajaran yakni seperti urutan yang ditampilkan pada Gambar 4.

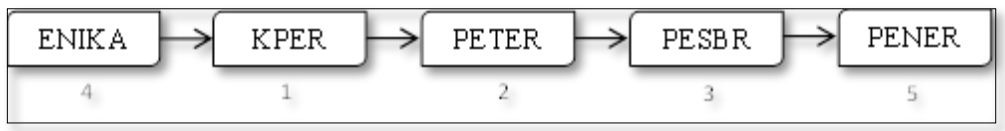

\section{Gambar 4. Urutan Penyajian Materi Berdasarkan Nilai Koefisien Korelasi Seluruh Sekolah}

Urutan penyajian materi pada seluruh sekolah berdasarkan nilai koefisien korelasi berbeda dengan urutan penyajian materi berdasarkan silabus. Ditinjau dari segi konsep, urutan pada Gambar 4 dapat disarankan untuk diterapkan dalam kegiatan pembelajaran. Sub pokok bahasan ENIKA dipilih sebagai urutan pertama untuk diajarkan karena sub pokok bahasan ini selain memuat konsep fakta juga memuat konsep yang berkaitan dengan pokok bahasan yang diajarkan sebelum termokimia yakni hidrokarbon. Senyawa-senyawa yang dibahas pada ENIKA ini lebih sering menggunakan senyawa hidrokarbon. Hal yang berkaitan dengan hidrokarbon seperti penamaan dan rumus struktur telah dibahas pada pokok bahasan hidrokarbon. Penguasaan konsep tentang rumus struktur senyawa merupakan salah satu prasyarat unruk sub pokok bahasan ENIKA. Alasan inilah yang menguatakan mengapa sub pokok bahasan ENIKA diajarkan pada urutan pertama. Sub pokok bahasan ENIKA berkorelasi cukup besar terhadap KPER. Hal ini disebabkan karena kedua sub pokok bahasan ini sama-sama membahas tentang energi. Energi yang dibahas pada ENIKA berupa energi yang diperlukan sistem baik untuk membentuk ikatan maupun memutuskan ikatan. Energi yang dibahas pada KPER adalah energi yang berpindah dari sistem kelingkungan atau sebaliknya sehingga menyebabkan munculya dua reaksi yakni reaksi eksoterm dan endoterm.

Urutan selanjutnya adalah PETER. Sub pokok bahasan ini memiliki korelasi paling tinggi terhadap KPER dibandingkan pada sub pokok bahasan 
lainnya. Hal ini disebabkan karena sub pokok bahasan ini sama-sama membahas tentang reaksi eksoterm dan endoterm. Urutan selanjutnya yakni PESBR. Sub pokok bahasan ini memuat konsep tentang reaksi-reaksi standar yang disertai dengan energinya. Reaksi standar ini juga dibahas pada PETER yakni tata cara penulisan reaksi tersebut. Alasan inilah mengapa sub pokok bahasan PESBR diajarkan setelah PETER. Urutan terakhir yakni sub pokok bahasan PENER. Sub pokok bahasan ini memiliki prasyarat yakni PETER dan PESBR. Artinya sudah tepat jika sub pokok bahasan ini diajarkan diakhir karena diajarkan setelah konsep prasyarat.

\section{Deskripsi korelasi antar sub pokok bahasan termokimia berdasarkan nilai} nilai rata-rata (mean) tes pada seluruh sekolah

Hubungan antar sub pokok bahasan dapat diurutkan dengan menggunakan nilai rata-rata (mean) tes. Nilai mean siswa diurutkan per sub pokok bahasan dari yang tertinggi ke terendah. Semakin besar nilai mean, maka letak urutan penyajian sub pokok bahasan semakin didahulukan. Nilai mean siswa untuk tiap sub pokok bahasan termokimia dinformasikan pada Tabel 4.

Tabel 4. Nilai Rata-Rata (Mean) dari Tes Siswa

\begin{tabular}{llllll}
\hline \multicolumn{5}{c}{ KPERPETERPESBRENIKAPENER } \\
\hline N Valid & 514 & 514 & 514 & 514 & 514 \\
\cline { 2 - 6 } Missing & 0 & 0 & 0 & 0 & 0 \\
\hline Mean & $\mathbf{3 , 1 6}$ & $\mathbf{2 , 0 2}$ & $\mathbf{1 , 6 7}$ & $\mathbf{1 , 4 3}$ & $\mathbf{1 , 9 7}$ \\
\hline \multicolumn{2}{l}{ Std. Deviation 1,664 } & 1,413 & 1,295 & 1,349 & 1,401 \\
\hline Minimum & 0 & 0 & 0 & 0 & 0 \\
\hline Maximum & 9 & 5 & 5 & 5 & 7 \\
\hline
\end{tabular}

Data pada Tabel 4 menunjukkan bahwa nilai mean terendah ada pada sub pokok bahasan ENIKA dan nilai mean tertinggi ada pada sub pokok bahasan KPER. Nilai mean tertinggi diletakkan diurutan pertama. Hal ini dilakukan karena semakin besar nilai mean, maka tingkat kesukaran sub pokok bahasan semakin mudah. Sebaliknya, semakin rendah nilai mean, maka tingkat kesukaran sub pokok bahasan semakin tinggi. Oleh karena itu, sub pokok bahasan dengan nilai mean terendah berada pada urutan terakhir. Urutan penyajian materi berdasarkan tingkat kesukaran (mean) antar sub pokok bahasan termokimia disajikan pada Gambar 5.

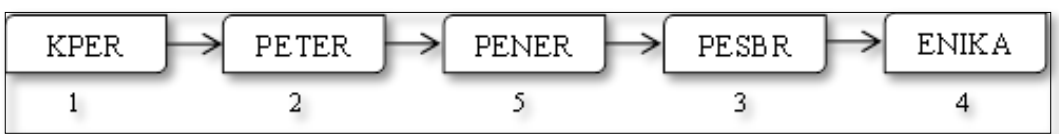

\section{Gambar 5. Urutan Penyajian Materi berdasarkan Nilai Rata-Rata (mean)}

Urutan penyajian materi pada Gambar 5 cukup mendekati urutan penyajian materi pada silabus khususnya pada urutan pertama dan kedua. Urutan 
ketiga (PENER) memang memiliki hubungan yang cukup kuat dengan kedua sub pokok bahasan yang diajarkan mendahuluinya. Sub pokok bahasan PENER diajarkan setelah PETER karena kedua sub pokok bahasan ini sama-sama membahas reaksi kimia. Reaksi yang dibahas pada PETER digunakan pada sub pokok bahasan PENER khususnya untuk menentukan perubahan entalpi reaksi berdasarkan hukum Hess, (diagram tingkat energi, diagram siklus dan reaksireaksi berhubungan). Urutan selanjutnya adalah PESBR. Sub pokok bahasan ini juga membahas reaksi kimia sehingga berkaitan dengan sub pokok bahasan PENER. Reaksi yang dibahas pada PESBR merupakan reaksi standar seperti reaksi pembentukkan, penguraian dan pembakaran standar. Urutan terakhir yaitu ENIKA. Sub pokok bahasan ini memuat konsep penentuan entalpi reaksi menggunakan data energi ikatan.

\section{KESIMPULAN}

Simpulan yang diperoleh dari hasil penelitian korelasi antar sub pokok bahasan termokimia pada siswa kelas XI MIPA SMA Negeri Palangka Raya Tahun ajaran 2018/2019, yaitu (1) Korelasi antar sub pokok bahasan termokimia berdasarkan nilai koefisien korelasi hasil tes kemampuan termokimia pada seluruh sekolah yakni diurutkan dari sub pokok bahasan ENIKA, KPER, PETER, PESBR, dan terakhir PENER. Urutan ini berbeda dari silabus dan disarankan untuk diterapkan dalam kegiatan pembelajaran karena ditinjau dari segi konsep telah sesuai karena materi prasyarat diajarkan terlebih dahulu. (2) korelasi antar sub pokok bahasan termokimia berdasarkan nilai rata-rata (mean) tes siswa yakni diurutkan dari sub pokok bahasan KPER, PETER, PENER, PESBR, dan yang terakhir ENIKA. Urutan ini juga dapat dicoba untuk diterapkan dalam pembelajaran karena berbeda dengan silabus.

\section{REFERENSI}

Agustin, Dewi. 2017. Kesulitan Siswa Kelas XI IPA SMA Negeri Kota Palangka Raya Tahun Ajaran 2016/2017 Dalam Memahami Konsep Penentuan Perubahan Entalpi Ditinjau Dari Hukum Hess. Skripsi Sarjana Tidak Diterbitkan. Universitas Palangka Raya

Alina. 2018. Korelasi Antar Topik Dalam Pokok Bahasan Hukum Dasar Kimia pada Siswa Kelas X-IPA SMA Negeri Palangka Raya Tahun Ajaran 207/2018. Skripsi Sarjana Tidak Diterbitkan. Universitas Palangka Raya.

Amri, Sofan dan Pourwati, L.E.2013. Panduan Memahami Kurikulum 2013. Jakarta : PT. Prestasi Pustakarya

Arifin, Zainal. 2012. Evaluasi Pembelajaran. Jakarta: Direktorat Jendral Pendidikan islam. Kementrian Agama RI

Dahar, R.W. 2011. Teori-Teori Belajar dan Pembelajaran. Jakarta : Erlangga

Dyah, Narum, Afi. 2017. Kimia Peminatan Matematika dan Ilmu-Ilmu Alam. Yogyakarta : Intan Pariwara 
Emzir. 2012. Metodologi Penelitian Pendidikan Kuantitatif dan Kualitatif. Jakarta : PT. Rajagrafindo Persada

Haryono dan Umiyati, Nurhalimah. 2014. Buku Siswa Kimia untuk SMA/MA XI Peminatan Matematika dan Ilmu-Ilmu Alam. Surakarta : CV Mediatama

Jonedi. 2016. Analisis Susunan Materi Pelajaran Kimia Kurikulum 2013 Berdasarkan Korelasi Dan Tingkat Kesukaran Kelas XI IPA Semester Ganjil Pada SMA Negeri Palangka Raya Tahun Ajaran 2014/2015. Skripsi Sarjana Tidak Diterbitkan. Universitas Palangka Raya

Jonathan Sarwono. 2010. PASW Statistics 18. Yogyakarta: CV Andi Offset

Muhidin, Maman Abdurrahman. 2007. Analisis Korelasi, Regresi, dan jalur dalam Penelitian(dilengkapi aplikasi program SPSS). Bandung: CV Pustaka Setia

Purwanto. 2012. Metode Penelitian Kuantitatif untuk Psikologi dan Pendidikan. Yogyakarta : Pustaka Belajar

Sudarmo, Unggul dan Mitayani, Nanik. 2015. Buku Siswa Edisi Revisi Kimia Untuk SMA/MA Kelas XI Kurikulum 2013 yang disempurnakan Peminatan Matematika dan Ilmu Pengetahuan Alam. Jakarta: Erlangga

Sujarweni, V.W. 2014. SPSS untuk Penelitian. Yogyakarta: Pustaka Baru Press Sukardi. 2008. Metodologi Penelitian Pendidikan: Kompetensi dan Praktiknya. Jakarta: Bumi Aksara

Sukmadinata, Nana Syaodih. 2009. Pengembangan Kurikulum Teori dan Praktek. Bandung: Remaja Rosdakarya

Siregar, Syofian. 2013. Metode Penelitian Kuantitatif. Jakarta: Kencana Prenada Media Group

Rachman, Taufik. 2018. Korelasi Antar Topik dalam Pokok Bahasan Ikatan Kimia pada Siswa Kelas X-IPA SMA Negeri di Kabupaten Katingan Tahun Ajaran 2017/2018. Skripsi Sarjana Tidak Diterbitkan. Universitas Palangka Raya. 